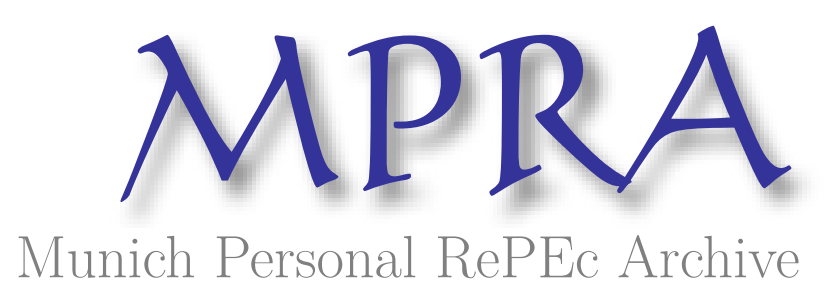

\title{
Determinant Factors of Employee Satisfaction in the Performance Appraisal Based on Management by Objectives
}

Gladisa, Fiera Wardhani and Susanty, Ade Irma

Telkom University, Telkom University

2017

Online at https://mpra.ub.uni-muenchen.de/92759/

MPRA Paper No. 92759, posted 15 Mar 2019 16:39 UTC 


\title{
Determinant Factors of Employee Satisfaction in the Performance Appraisal Based on Management by Objectives
}

\author{
Fiera Wardhani Gladisa ${ }^{1}$, Ade Irma Susanty ${ }^{2}$ \\ Schools of Economy dan Bussiness, Telkom University \\ Schools of Communication dan Bussiness, Telkom University, \\ Bandung, Indonesia
}

fieragladisa@telkomuniversity.ac.id, adeirma@telkomuniversity.ac.id

\begin{abstract}
Abstrak
In response to the phenomenon of low employee satisfaction level on performance appraisal, organization nowadays need to identify the determinants of employee satisfaction in the performance appraisal. The purpose of this article is to develop a conceptual framework about the determinants of employee satisfaction in performance appraisal using the effectiveness of performance appraisal approach.
\end{abstract}

The review of this article using three approaches. First, this article discusses the relevance of employee satisfaction with performance appraisal. Second, review the literature about performance appraisal effectiveness as determinants of employee satisfaction in the performance appraisal. Third, integrating the types of performance appraisal systems in organizations with a determinants model of employee satisfaction in the performance appraisal in order to develop a comprehensive framework for the organization.

A determinants practical model of employee satisfaction in the performance appraisal based on management by objectives has been obtained. This model adopts the performance appraisal model with the changes caused by adjustments to the appraisal basis management by objectives. This shows that employee satisfaction in performance appraisal can be obtained from the effectiveness performance appraisal system.

Keywords: performance appraisal; employee satisfaction; effectiveness of the performance appraisal system.

\section{Introduction}

Employee is the only organizational resource which has ratio, feel, and intention that affect the organization's efforts in achieving goals because employee has a role as the driving force of all the resources owned organization. Therefore, employees will always be a benchmark in the management of the organization to consider any decision relating to salaries, with project work to be done, and also with social rules on which the organization was sheltering (Colquitt, 2001). In response, the idea that an employee in the workplace must be assessed is eminently reasonable.

Performance appraisal has widened as the concept of performance management implementation has been part of a strategic approach to integrating HR activities with the company's policy (Fletcher, 2010). Appraisal performance procedures potentially bring substantial benefits for both employees and the organization, where the feedback from an appraisal can be referred by an employee to set goals that can be used by the employee and the organization as a tool to evaluate and improve their performance (Swanepoel, et al. 2014).

The purpose of performance appraisal by Palaiologos et al. (2011) is for administrative purposes (consideration of salary increases, bonuses, promotions, recruitment and employee pension) and for the needs of development (increased competence as well as education and training considerations). Therefore, when it has impact on the compensation obtained, then an employee will take the job seriously and automatically increases employee satisfaction (Stringer et al, 2011). Supporting the statement, according to Poon (2004) when the value of the performance becomes a consideration in determining opportunities for administrative and development, the

[Type here] 
Pre-print : Gladisa, F.W.; Susanty, A.I (2018) Determinant Factors of Employee Satisfaction in the Performance Appraisal Based on Management by Objectives, Proceeding book of International Conference on Sustainable Collaboration in Business, Technology, Information, and Innovation $8^{\text {th }}, 241-246$

performance appraisal will affect employee satisfaction. Low satisfaction may have a negative impact on organizational commitment (Judge et al, 2001).

Facing the global challenges, organizations need human resources who are committed and have a high work 
Pre-print : Gladisa, F.W.; Susanty, A.I (2018) Determinant Factors of Employee Satisfaction in the Performance Appraisal Based on Management by Objectives, Proceeding book of International Conference on Sustainable Collaboration in Business, Technology, Information, and Innovation $8^{\text {th }}, 241-246$

ethic. According Stevers \& Joyce (1999), the commitment and performance of employees depends on the evaluation and perceptions of employees in the performance appraisal practices. Therefore, it is necessary to examine more about performance appraisal and the factors that determine employee satisfaction in the performance appraisal across an organization.

\section{Literature Review}

\section{Performancene Appraisal Based on Management by Objectives}

Performance is the willingness of a person or group of people to do something and refine activities in accordance with its responsibilities in order to obtain the expected results (Rivai \& Basri, 2005). Rivai \& Basri (2005) added, the performance is basically determined by three things: the ability, desire, and the environment. Meanwhile, according to Dessler (2006) basically the employee's performance is more a function of training, communications, tools, and control rather than personal motivation. In other words, the performance can be associated with a positive contribution to the organization's employees.

The way to measure the employee's contribution to the organization he worked for was by conducting performance appraisal (Bernardin \& Russell, 1993). The performance appraisal refers to a formal and structural system used to measure, assess, and affect the properties associated with the work, behavior, and the results, including absenteeism (Rivai \& Sagala, 2009). So that, a performance appraisal can encourage responsibility and accountability of employees (Flaniken, 2009).

During the past centuries, the organization can survive without their performance appraisal (Wiese \& Buckley, 1998). But as the times, the current performance appraisal is an integral element of organizational life (Cintron \& Flaniken, 2011). Performance appraisal system that exists today has evolved over time since it was first used in the early 1800s (Wiese \& Buckley, 1998). One performance appraisal method currently used is Management by Objectives (MBO).

MBO system has been introduced since 1950 (Wiese \& Buckley, 1998). Step of MBO prosess started after the employee and the leader agree with their job and responsibility for certain period of times, then continue by determining specific target, measured, and has a limit time for those tasks (Wiese \& Buckley, 1998). The final performance appraisal conducted at the end of the deadline that has been determined and based on the appraisal of the achievement of the employee towards the agreed targets (Wiese \& Buckley, 1998) This system is believed to have advantages such as: redefining the role of management to help employees achieve goals; boost employee confidence on the appraisal as specified target together, than if the appraisal is based upon the observation of behavior; and shift the orientation of the appraisal of "past behavior" to "future acts" (Wiese \& Buckley, 1998). According to Wiese \& Buckley (1998: 240), the main problem of this system is the need for a strong commitment from management and the time required to reorient the employees thought.

\section{Determinants of satisfaction on performance appraisal based on Mangement by Objectives}

According to the research conducted by the Keeping \& Levy (2000) employee satisfaction in the performance appraisal will affect the effectiveness of the performance appraisal itself. Employee satisfaction may include satisfaction with the performance appraisal system, satisfaction with the implementation of performance appraisal, satisfaction with the perceived benefits of performance appraisal (Keeping \& Levy, 2000), and satisfaction with the fairness and objectivity of performance appraisal (Keeping \& Levy, 2000; Jawahar 2007; Cintron \& Flaniken, 2011). If employees believe that the performance appraisal process is already fairly applied, the employee is more likely to be satisfied and recognizes the performance evaluation results obtained, even the performance evaluation results despite unfavorable (Cintron \& Flaniken, 2011). Meanwhile, according to Ochoti, et.al (2012), efforts to increase employee satisfaction in the performance appraisal one of which is precisely to build an effective performance appraisal system that is relevant appraisal system, not bias, and not contain the political interests of the organization. 
(Ikramullah, et.al., 2016. The purpose of performance appraisal that is relevant to the organization's goals is necessary for the effectiveness of the performance appraisal system (Boice \& Kleiner, 1997; Ochoti, et.al., 2016; Ikramullah, et.al., 2016). Generally, the purpose of performance appraisal is for administrative needs (Palaiologos et al., 2011) and development requirements (Ikramullah, et .al., 2016). If the employee does not feel the benefits of the purpose of the performance appraisal, so it should be reconsidered because it can decrease the number of employees satisfaction (Agyare, et.al., 2016).

Furthermore, in planning and establishing performance targets need to be matched to the determined purpose (Ikramullah, et.al., 2016). This is due to the planning and establishment of appropriate target would be effective to measure the performance achieved (Keeping \& Levy, 2000; Ikramullah, et.al., 2016). If the target has been set, it needs constant control to oversee the achievement of predetermined targets (Boice \& Kleiner, 1997; Jawahar, 2006). In addition, routine monitoring also helps superiors (appraisers) in its appraisal that not only focus on results, but considering the overall process (Ikramullah, et.al., 2016). The regulatory process can be coupled with counseling and coaching for employees to help employees deal with problems at work (Ikramullah, et.al., 2016). Through direct coaching by leader, employees will feel confident and feel treated with respect.

After the performance value is obtained, then the feedback should be given so employees can determine the extent to which the achievement of an employee against the company's expectations and to help employees plan targets in the future (Ikramullah, et.al., 2016). In the stages of the appraisal process from beginning to end, required good communication between leader and employee under (Ochoti et.al., 2012; Ikramullah, et.al., 2016). So that needs to be carried out training for management-related insight into the performance appraisal (Ochoti et.al., 2012). Communication and employee engagement can reduce the chances of conflict between leader and employee (Ikramullah, et.al., 2016).

Beside the things taht mentioned earlier, Ochoti et.al. (2012) also found employee attitude or perception of employee plays an important role. If the system is already deemed biased already, irrelevant, or politically, the dissatisfaction with the system can not be avoided (Ochoti et.al., 2012). Talking about the quality of performance appraisal, Showkat (2013) is generally argued that the effectiveness appraisal focuses on: the design of the performance appraisal system; its process involving the employer as well as a program evaluator organizations to reinforce the achievement of the performance; the output of the function of the process of performance evaluation results; as well as other things in the organization that affect satisfaction in the performance appraisal.

Research conducted by Rowland \& Hall $(2012 ; 2013)$ looked at satisfaction in the performance appraisal of the fairness perceived by the employees. Performance appraisal often creates inequities in terms of procedure and benefits, both real injustice and presumption (Rowland \& Hall, 2012). Therefore, a fair evaluation is not just about developing the right form, but it depends on the openness and willingness of all parts involved to try to see things from another point of view. Justice is what will affect employee satisfaction (Thursthon Jr. \& McNall, 2009).

Based on the reviews, the determinants of employee satisfaction in the performance appraisal obtained by the effectiveness of performance appraisal systems approach and employee notion of justice. When the effective performance appraisal, the employee will be satisfied (Showkat, 2013). So the determinants of employee satisfaction in the performance appraisal can be described in the following conceptual framework: 
Pre-print : Gladisa, F.W.; Susanty, A.I (2018) Determinant Factors of Employee Satisfaction in the Performance Appraisal Based on Management by Objectives, Proceeding book of International Conference on Sustainable Collaboration in Business, Technology, Information, and Innovation $8^{\text {th }}, 241-246$

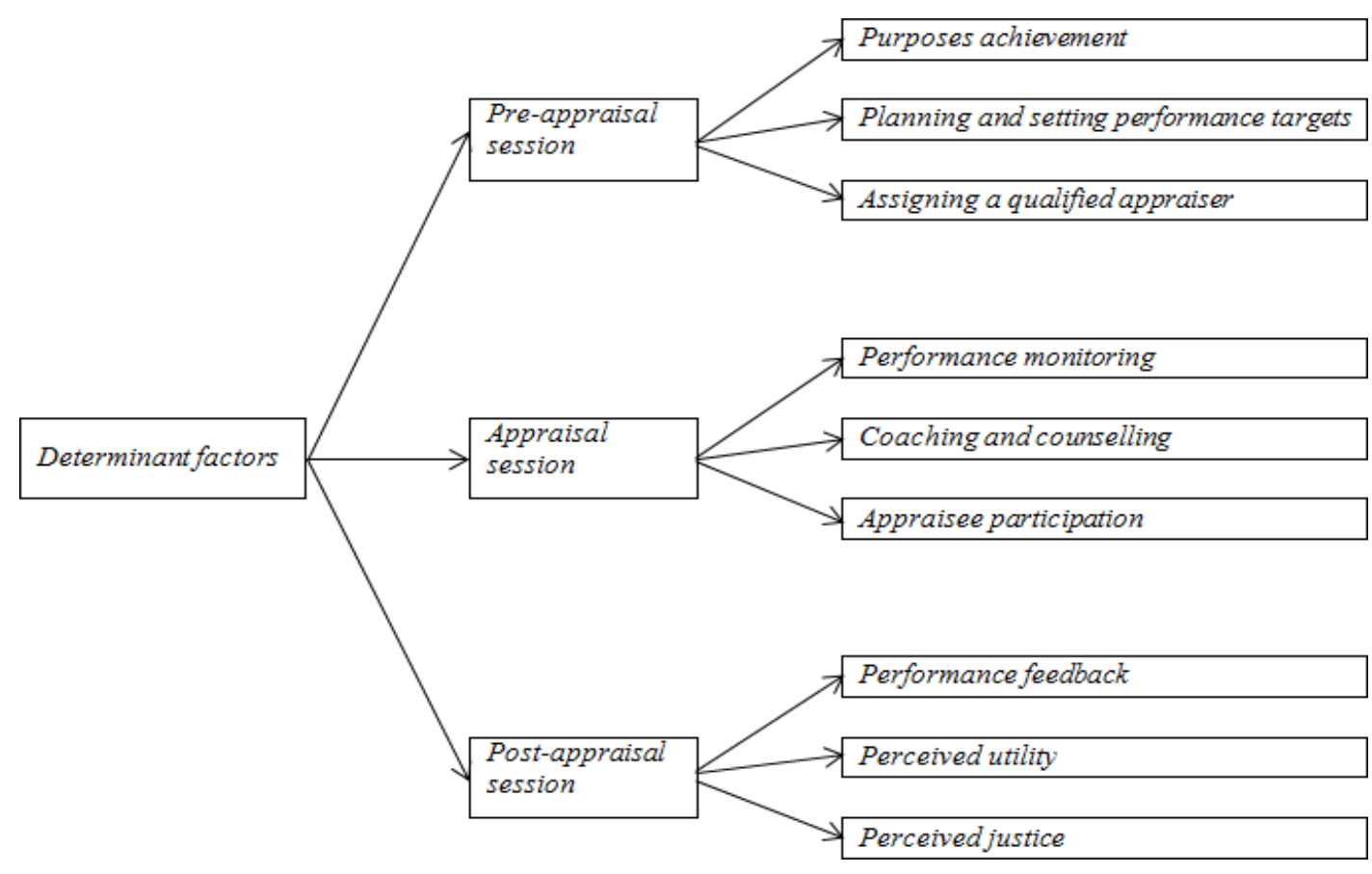

Fig. Framework of Determinant Factors of Employee Satisfaction in the Performance Appraisal Based on Management by Objectives

\section{Conclusion and Suggestion}

Based on the review of previous research, obtained the determinants of employee satisfaction in the performance appraisal with the determinants of performance appraisal efectiveness approach. The model can be applied in the organization that implement the performance appraisal system based on management by objectives. Further research can explore the significant factors that determine employee satisfaction in performance appraisal. In addition, further research may also examine the influence of the determinants of employee satisfaction in the performance appraisal toward the desired variable.

\section{References}

Agyare, Ramous., Yuhui, Gu., Mensah, Lavish., Aidoo, Zipporah., \& Ansah, Isaac Opoku. (2016) 'The impacts of performance appraisal on employees' job satisfaction and organizational commitment: a case of microfinance institutions in ghana', International Journal of Business and Management; Vol.11 No.9, pp.281-297.

Bernardin, H. John., \& Russel, Joyce E.A., (1993). Human Resources Management: An Experiental Approach. Terjemahan. Jakarta: Pustaka Binaman Presindo.

Boice, Deborah F., \& Kleiner, Brian H. (1997) 'Designing effective performance appraisal systems', Work Study, Vol.46 No.6, pp.197-201.

Cintron, Rosa., \& Flaniken, Forrest. (2011) 'Performance appraisal: a supervision or leadership tool', International Journal of Business and Social Science, Vol.2 No.17, pp.29-37.

Colquitt, Jason A. (2001) 'On the dimesionality of organizational justice: a construct validation of a measure', 
Pre-print : Gladisa, F.W.; Susanty, A.I (2018) Determinant Factors of Employee Satisfaction in the Performance Appraisal Based on Management by Objectives, Proceeding book of International Conference on Sustainable Collaboration in Business, Technology, Information, and Innovation $8^{\text {th }}, 241-246$

Fletcher, Clive. (2001) 'Performance appraisal and management: the developing research agenda', Journal of Occupational and Organizational Psychology, Vol.74 No.4, pp.473-487.

Guest, D. E. (1999), Human Resource Management - The Workers' Verdict. Human Resource Management Journal, 9, 5-25. doi:10.1111/j.1748-8583.1999.tb00200.x

Ikramullah, Malik., Shah, Bahadar., Khan, Shadiullah., Hassan, Faqir S., \& Zaman, Tariq. (2012) 'Purpose of performance appraisal system: a perceptual study of civil servants in district Dera Ismail Khan Pakistan', International Journal of Business and Management. Vol.7 No.3, pp.142-151.

Jawahar, I.M. (2007) 'The influence of perceptions of fairness on performance appraisal reactions', Journal of Labor Research, Vol.28 No.4, pp.735-754.

Judge, T.A., Bono, J.E., Thoresen, C.J., \& Patton, G.K. (2001) 'The job satisfaction - job performance relationship: a qualitative and quantitative review', Psychology Bulletin, Vol.127 No.3, pp.376-407.

Keeping, Lisa., \& Levy, Paul E. (2000) 'Performance appraisal reactions:measurement, modeling, and method bias', Journal of Applied Psychology, Vol.85, pp.708-723.

Ochoti, George N., Maronga, Elijah., Muathe, Stephen., Nyabwanga, Robert N., \& Ronoh, Peter K. (2012) 'Factors influencing employee performance appraisal system: a case of the ministry of state for provincial administration \& internal security, Kenya', International Journal of Business and Social Science. Vol.3 No.20, pp.37-46.

Palaiologos, Anastasios., Papazekos, Panagiotis., \& Panayotopoulou, Leda. (2011) 'Organizational justice and employee satisfaction in performance appraisal', Journal of European Industrial Training, Vol.35 No.8, pp.826-840.

Poon, June M.L. (2004) 'Effects of performance appraisal politics on job satisfaction and turnover intention', Personnel Review, Vol.33 No.3, pp.322-334.

Rivai, Veithzal., \& Basri. (2005) Performance Appraisal: Sistem yang Tepat untuk Menilai Kinerja Karyawan dan Meningkatkan Daya Saing Perusahaan, Rajagrafindo Persada. Jakarta.

Rivai, Veithzal.,\& Sagala, Ji. (2009) Manajemen Sumber Daya Manusia, Jakarta : Rajawali Pers.

Rowland, Caroline A., \& Hall, Roger D. (2012) 'Organizational justice and performance: "is appraisal fair?"', EuroMed Journal of Business. Vol.7 No.3, pp.280-293.

Rowland, Caroline A., \& Hall, Roger D. (2013) 'Perceived unfairness in appraisal: engagement and suistainable organizational performance', EuroMed Journal of Business. Vol.8 No.3, pp.195-208.

Showkat, Shagufta. (2013) 'Performance appraisal in banking organizations', Journal of Arts, Science \& Commerce. Vol.3 No.1, pp.66-79.

Swanepoel, Sonia., Botha, Petrus A., \& Mangonyane, Nancy B. (2014) 'Politicisation of performance appraisals', SA Journal of Human Resource Management. Vol.12 No.1, pp.525-533.

Stringer, Carolyn., Didham, Jeni., \& Theivananthampillai, Paul. (2011) 'Motivation, pay satisfaction, and job satisfaction on front-line employees', Qualitative Research in Accounting \& Management, Vol.8 No.2, pp.161-179.

Thusrston, Paul W., \& McNall, Laurel. (2010) 'Justice perceptions of performance appraisal practices', Journal 